irregular in shape in iritis; in glaucoma it is dilated, sluggish and may be greenish in color; whereas in the other two diseases it is not affected.

Vision is slowly impaired in iritis; but in glaucoma there is rapid and marked loss early in the attack; in keratitis it is more or less blurred, depending on the amount of haziness or opacity of the cornea; in conjunctivitis it is very slightly interfered with on account of mucus and tears flowing over the cornea.

Field of vision is contracted in glaucoma, but in the other affections it is not.

Cupping of disk is present in glaucoma, and it may be seen by the aid of the ophthalmoscope provided the media are not too turbid; it is absent in the other three affections.

Pain is severe and similar in character in both glaucoma and iritis, but in the former it is not apt to be worse at night; in keratitis it is not so marked, but is more constant; in conjunctivitis it is more of a smarting or burning sensation, as if there were sand in the eye, than actual pain.

Photophobia is intense and very conspicuous in keratitis; it is less troublesome in iritis and glaucoma, and in conjunctivitis it is hardly noticeable.

\section{A CASE OF CHRONIC GLOMERULO-NEPHRITIS IN WHICH DOUBLE DECAPSULATION WAS PERFORMED.}

\section{Visiting Surgeon at St. Elizabeth's Hospital; Consulting Surgeon at the Quincy City Hospital, Quincy, Mass.; Member of the A merican Gynecological Association.}

A. B., a girl aged fifteen years, was first seen in July, 1905. The patient had had an attack of scarlet fever at one year of age. No details could be gotten in regard to the severity of the attack, and it was probably an ordinary case of the disease. She had whooping cough at four years of age, but beyond this there was nothing of note.

She had exhibited marked symptoms of nephritis for a year, the disease having been ushered in by swelling of the eyelids. This led to an examination of the urine and a diagnosis of chronic nephritis was easily made.

When first seen the patient had edema of the eyelids, fect and legs. Pitting of the skin was deep and the face was puffy and swollen. She suffered somewhat from headaches, but there was no other pain. She slept well, the appetite was good and there was no vertigo. Beyond a general feeling of lassitude and disinclination to exert herself she did not suffer very much.

Her catamenial periods came on at the usual time, at about the age of ten years, and they were regular in time until about a year ago when they ceased entirely.

On examination she presents the appearance of an undersized girl, rather poorly developed mentally, but there is no serious defect. She has a pasty look and appears sick. Lungs are negative, but the heart is enlarged and the apex beat is nearly in the nipple line. There are no murmurs.

The operation was performed at St. Elizabeth's Hospital on July 18, 1905, with the assistance of Dr. C. H. Hare. The patient was placed on an Edebohl's roll pad, lying flat on her face, and the two kidneys were readily exposed. Dr. Hare did one side, and the writer the other. The kidneys were enlarged to about twice the normal size. They were perfectly regular in outline and they were yellow and mottled on the surface. They were soft and the capsule over them was very thin and was easily stripped off and cut away near the hilus. There was no compression of the kidney substance by the capsule, for the latter was spread over the surface of the organ very loosely. A small piece of kidney tissue was excised for examination.

The greatly enlarged kidneys were in marked contrast to the very small atrophied cirrhotic kidneys which were removed at the autopsy nearly three years later.

Immediately after the operation, there was a good deal of vomiting and general prostration and it was thought that she must succumb. At the end of a few days, however, she rallied, and from that time until her discharge from the hospital the convalescence was uneventful. During the first twenty-four hours she passed only $180 \mathrm{ccm}$. of urine, which contained only a trace of albumen. This was in marked contrast with the amount of albumen just preceding the operation. Two days before it was performed there was $1 \%$ and three days before there was $\frac{1}{4} \%$. Two days after the operation she passed $555 \mathrm{ccm}$. of urine with a large trace of albumen. Four days after the operation the amount of urine was 720 . ccm. with $\frac{1}{2} \%$ of albumen. The amount of albumen stayed fairly high, as will be seen by referring to the chart, until July 31, 1905, when it dropped to $\frac{1}{8} \%$ again. In November she was passing $2,000 \mathrm{ccm}$. of urine with $\frac{1}{8} \%$ of albumen and the amount remained large until a short time before her death, when it rapidly decreased.

The following notes are taken from my note-book:

Aug. 28, 1905. For seven days has had severe headache over the eyes. Last week vomited twice. Much less edema of the feet and legs and she has had edema under the eyes only once since the operation. She feels very much better in every way. Pathological report, Dr. W. H. Prescott and Dr. F. B. Mallory: Subacute glomerulo-nephritis.

Nov. 18,1905 . Is feeling very well. No edema, no nausea, no headache, no subjective symptoms of any kind. Sleeps well and looks better than she has for a long while. Runs around and plays with other children and there is nothing to suggest any serious disease. Is taking Blaud's pills. Patient has been very much improved by the operation and she says herself that she is much better.

Jan. 15, 1906. No headaches, no dizziness, good appetite, regular bowels, some edema of the feet and hands. Urination three or four times a day and once at night.

May 6,1906 . Good appetite, some edema of the feet and face, some dyspnea, otherwise comfortable.

Oct. 18, 1906. The patient has until now been very comfortable indeed. She has done nearly as much as girls of her age usually do and she has not been distressed in any way by her affection, but lately she has begun to fail. There is a yellow, pasty color, a considerable degree of emaciation and some edema of the face and legs. Her appetite continues good, her bowels are regular, she sleeps well and she is able to be about.

Feb. 27, 1907. About the same as she was when last seen. Dr. F. I. Proctor examined both eyes and reported the fundi to be normal.

March 13, 1907. Has improved a little. Looks better, has less edema.

April 2, 1907. Has been vomiting a good deal lately. July 15, 1907. There is more edema and some nausea. She is failing. She is pale, anemic, has lost more flesh and her appetite is not very good.

March 11, 1908. Died to-day. For the past few months has failed rapidly, emaciation increased, nausea and vomiting came on, the urine began to diminish in amount and towards the end there were numerous convulsions, in one of which she died. 
Looking at the case as a whole, I feel convinced that her life was prolonged, that she suffered less, and that she was decidedly improved, by the operation. I should say that the improvement was shown in the following ways: There was certainly much less edema, she was much stronger and she could do more for at least two years after the operation than she had done during the year preceding it.

A glance at the chart herewith appended shows the examinations of the urine from time to time. It will be noticed that immediately following the opcration there was a rapid diminution in the amount of albumen. It soon increased and continued to be considerable in amount until November, 1905, five months after the operation. At that time there was only a trace to $\frac{1}{8} \%$ and this continued so until March 12 , 1907, which was the last time an examination was made. Just before death urine was very scanty in amount and contained a great deal of albumen.

The autopsy was performed by Dr. A. R. Robertson of the Harvard Medical School. His report is herewith given.

It is interesting to note that the type of nephritis in this case was one affecting the glomeruli. The malevolent influence of an early scarlet fever is manifest in this case and suggests that a nephritis should always be borne in mind if a patient has once had this disease. It is particularly to be borne in mind in a person who has had scarlet fever after puberty. The disease may not be suspected at all and the patient may go on for a number of years without any treatment until suddenly symptoms of impaired renal functions manifest themselves. In women it is especially dangerous because during pregnancy the kidneys may suddenly fail.

Autopsy, March 11, 1908, by Dr. A. R. Robertson. A. B., age seventeen. Four hours post-mortem.

The body is that of a slim young white female about five feet in height, of rather poor nutrition. The skin is sallow, dry, but cannot be pinched up; no palpable glands; no markings on body of recent character. In the each lumbar region there is an oblique linear scar of an old operation wound about $10 \mathrm{~cm}$. in length. The scar commences 2 or $3 \mathrm{ccm}$. below the costal margin about $5 \mathrm{~cm}$. from median line and extends obliquely downwards and outwards. Axillary and pubic hair very scanty. Pupils: left, $6 \mathrm{~mm}$.; right, $3 \mathrm{~mm}$. There is a slight opacity of the right cornea in its lower half due to non-closure of the lids (post-mortem). No edema of extremities or trunk; there is a dark waxy exudate in left external auditory meatus. The abdomen is considerably stained with opium liniment. The subcutaneous fat is of a dark golden-yellow color and very tough. It measures about $3 \mathrm{~mm}$. over the chest and $6 \mathrm{~mm}$. over the abdomen.

Peritoneal cavity. - Diaphragm right fourth rib, left fourth interspace. Fat of great omentum is very scanty. Mesenteric lymph nodes are palpable and visible; of a light bluish tint. They are not enlarged. Appendix measures $10 \mathrm{~cm}$., points towards the spleen, has a mesentery nearly to tip and is free from adhesions. The bladder is distended, completely fills pelvis, and reaches to a point midway between umbilicus and pubis. A very dense band of adhesions extends from the posterior parietal peritoneum overlying the right kidney to the inferior surface of the right hepatic lobe about $3 \mathrm{~cm}$. to the right of the gall bladder. The latter is well filled with fluid bile; there are no adhesions elsewhere. There is no free fluid. The intestines are almost free of gas.

Pleural cavities. - Free of fluid and adhesions.

Pericardial cavity. - The serosa is smooth, pale and glistening; over the right ventricle there is a small opaque patch of pericardial thickening; there is a similar spot over the left ventricle. There are about $15 \mathrm{ccm}$. of clear straw-colored fluid.

Heart. - Weight, $275 \mathrm{gm}$. The right side is dilated with fluid blood. The left side is firmly contracted. On section the myocardium is of a uniform pale pinkish color and of firm consistence. Endocardium is pale and smooth throughout; the valves are thin and flexible.

T., 10.7; P., 5.6.; M., 8; A., 5.6; R. V., .4; L. V., 1.6 . Interventricular septum, $1.1 \mathrm{~cm}$.

Coronaries are patent and the intima of uniform smoothness throughout.

Lungs. - Contain a little air and are collapsed into the posterior portion of the chest. They are of pale grayish and in places pinkish color. Very dry on section, soft, crepitant and elastic; the bronchial mucous membrane is pale and smooth. The peribronchial glands are small, deeply pigmented with carbon and firm.

Liver. - Weight about 1,400 gm.; surface, dark brown and smooth except for the band of adhesions above mentioned; edges sharp. On section the lobulation is quite distinctly marked, the lobules being of chocolate-brown color; consistence firm but not increased. The gall bladder is thin walled and contains about $50 \mathrm{ccm}$. of dark fluid bile. Bile passages are patent.

Spleen. - Weight 70 gm. ; surface smooth, of deep reddish-brown color, edges sharp, organ firm. On section the Malpighian bodies are of good size, averaging .5 to $1 . \mathrm{mm}$., somewhat irregular, and the trabeculæ are quite distinct; the pulp is very firm and does not scrape.

Pancreas. - Of light gray color and of uniform firmness; on section the lobules are very well marked.

Gastro-intestinal tract. - Stomach contains an abundance of frothy dark greenish-brown bile-tinged fluid, in which there is no trace of food. The mucous membrane is pinkish and smooth, the small intestines throughout contain semifluid dark greenish feces. In the large intestine the feces are solid and of a similar color. Mucous membrane of small and large intestine is also pale and smooth.

Adrenals. - Are of good size and firm; cortex is of deep yellowish color; medulla brown.

Kidneys. - The left kidney is removed in toto with its perirenal tissues, artery, vein and adrenal.

The right kidney is surrounded with very dense perirenal tissue containing tough fat in small quantities. The organ has a rough surface and very firm nodular consistence. Its capsule is very thick, strips with some difficulty, leaving a coarsely granular surface. On section the cut surface is pale, medulla being of very slightly darker color than the cortex; the cortex measures about $3.5 \mathrm{~mm}$., and in it the glomeruli stand out prominently as large slightly pinkish dots. There are scattered irregular small areas and streaks of yellowish color, especially marked at the bases of the pyramids. The streaks often extend into the pyramids for several millimeters; the medulla shows these yellowish radiating streaks principally at the bases of the pyramids, but also close to the apices. The pelves are small and are surrounded with a small
The 
Urine Chart of A. B.

\begin{tabular}{|c|c|c|c|c|c|c|}
\hline & March 17, 1905 & April 17, 1905 & June 1, 1905. & July 5,1905 . & July 8, 1905. & July 11, 1905. \\
\hline \multirow[t]{2}{*}{$\begin{array}{l}\text { Amount } \\
\text { Urea } \\
\text { Color } \\
\text { Chlorides } \\
\text { Specific gravity } \\
\text { Solids } \\
\text { Reaction } \\
\text { Albumen } \\
\text { Bile } \\
\text { Sugar } \\
\text { Sediment }\end{array}$} & \begin{tabular}{|c|} 
Pale \\
1,010 \\
\\
$\frac{1}{4} \%$ \\
A number of \\
fine granular \\
and hyaline \\
casts, with \\
fatty renal \\
cells adher- \\
ent; consider- \\
able free fat; \\
many fatty \\
renal cells.
\end{tabular} & \begin{tabular}{|l}
$\frac{1}{4} \%$ to $\frac{1}{2} \%$ \\
Many small, \\
round fatty \\
cells ; much \\
fat, free and \\
in clumps; a \\
number of \\
fatty a n d \\
hyaline casts \\
with fatty \\
renal epithe- \\
lium adher- \\
ent.
\end{tabular} & $\begin{array}{l}\text { Many hyaline } \\
\text { granular and } \\
\text { e p i th e lial } \\
\text { casts ; many } \\
\text { fatty renal } \\
\text { e p i th e l i a } \\
\text { free and ad- } \\
\text { herent to } \\
\text { casts; com- } \\
\text { pound gran- } \\
\text { ule cells. }\end{array}$ & $\begin{array}{l}\text { Normal } \\
1,011 \\
\text { Acid } \\
\frac{1}{4} \% \\
\text { Large; chiefly } \\
\text { a m o r phous } \\
\text { p h o s phates; } \\
\text { medium and } \\
\text { small round } \\
\text { e pi t h e li a; } \\
\text { c o m p u nd } \\
\text { granule cells; } \\
\text { renal epi- } \\
\text { thelium with } \\
\text { fat adherent; } \\
\text { small amount } \\
\text { of blood. }\end{array}$ & $\begin{array}{l}7 \text { gm. } \\
\text { Pale } \\
1,000 \\
15 \text { gm. } \\
\text { Slightly acid } \\
\frac{1}{3} \% \\
0 \\
\text { Fairly numerous } \\
\text { hyaline finely } \\
\text { and coarsely } \\
\text { g r a n u l a r } \\
\text { casts, many } \\
\text { with fatty } \\
\text { renal epi- } \\
\text { thelium ad- } \\
\text { herent. Few } \\
\text { fatty renal } \\
\text { e p i th e lia } \\
\text { le u c o c y tos } \\
\text { and abnor- } \\
\text { mal blood } \\
\text { cells free and } \\
\text { adherent to } \\
\text { casts. }\end{array}$ & 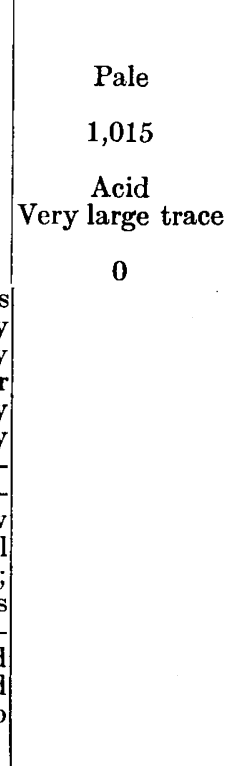 \\
\hline & July 15,1905 . & July $16,1905$. & $\begin{array}{c}\text { (Day before } \\
\text { operation.) } \\
\text { July } 17,1905 .\end{array}$ & $\begin{array}{l}\text { (Day after } \\
\text { operation.) } \\
\text { July } 19,1905 .\end{array}$ & July 20, 1905. & July $22,1905$. \\
\hline \multirow[t]{2}{*}{$\begin{array}{l}\text { Specific gravity } \\
\text { Solids } \\
\text { Reaction } \\
\text { Albumen } \\
\text { Bile } \\
\text { Sugar } \\
\text { Sediment }\end{array}$} & $\begin{array}{c}1,440 \\
14.54 \\
\text { High } \\
\text { Slight trace } \\
\\
1,014 \\
45.27 \\
\text { Acid } \\
10 \% \\
0 \\
0\end{array}$ & $\begin{array}{c}1,050 \\
18.58 \\
\text { Cloudy } \\
\text { Slightly } \\
\text { diminished } \\
1,021 \\
51.37 \\
\text { Acid } \\
1 \% \\
0 \\
0\end{array}$ & $\begin{array}{c}1,110 \\
6.99 \\
\text { Clear } \\
\\
1,018 \\
46.55 \\
\text { Acid } \\
\frac{1}{8} \%\end{array}$ & $\begin{array}{l} \\
\text { sizes; compour } \\
\text { and small ro } \\
\text { granular; larg } \\
\text { casts; some blo }\end{array}$ & \begin{tabular}{|}
555 \\
9.10 \\
High \\
\\
1,018 \\
23.27 \\
Acid \\
Large; trace \\
\\
Large; chiefly \\
cells of all \\
ind granule cells; \\
ound epithelium \\
ge hyaline gran \\
lood; uric acid cr
\end{tabular} & $\begin{array}{l}\text {; large, medium } \\
\text { n, all fatty or } \\
\text { nular and fatty } \\
\text { rystals. }\end{array}$ \\
\hline & July 23, 1905. & July $24,1905$. & July $25,1905$. & July 26, 1905. & July 27, 1905. & July 28, 1905. \\
\hline $\begin{array}{l}\text { Amount } \\
\text { Urea } \\
\text { Color } \\
\text { Chlorides } \\
\text { Specific gravity } \\
\text { Solids } \\
\text { Reaction } \\
\text { Albumen } \\
\text { Bile } \\
\text { Sugar } \\
\text { Sediment }\end{array}$ & $\begin{array}{c}1,015 \\
30.40 \\
\text { Acid } \\
\frac{1}{2} \%\end{array}$ & $\begin{array}{l}1,015 \\
20.97 \\
\text { Acid } \\
\frac{1}{4} \%\end{array}$ & $\begin{array}{c}1,016 \\
28.03 \\
\text { Acid } \\
\frac{1}{2} \%\end{array}$ & $\begin{array}{c}525 \\
\\
\text { Normal } \\
1,016 \\
19.57 \\
\text { Acid } \\
1 \%\end{array}$ & $\begin{array}{c}720 \\
13.60 \\
\\
\text { Normal } \\
1,014 \\
23.48 \\
\text { Acid } \\
1 \%\end{array}$ & $\begin{array}{l}\text { 550 } \\
6.43 \\
\text { Amber } \\
\\
1,012 \\
16.09 \\
\text { Acid } \\
\frac{1}{2} \% \\
\\
\text { Large; consists } \\
\text { of s m a 11 } \\
\text { round and } \\
\text { m e d i u m } \\
\text { round epi- } \\
\text { thelium, all } \\
\text { fatty or gran- } \\
\text { ular; fatty } \\
\text { hyaline and } \\
\text { granular casts } \\
\text { of small and } \\
\text { large diame- } \\
\text { ter. }\end{array}$ \\
\hline
\end{tabular}


Urine Chart of A. B. - (Continued.)

\begin{tabular}{|c|c|c|c|c|c|c|}
\hline & July $30,1905$. & July 31, 1905. & A ugust 1, 1905. & August 2, 1905. & August 3, 1905. & August 4, 1905 . \\
\hline \multirow[t]{2}{*}{$\begin{array}{l}\text { Amount } \\
\text { Urea } \\
\text { Color } \\
\text { Chlorides } \\
\text { Specific gravity } \\
\text { Solids } \\
\text { Reaction } \\
\text { Albumen } \\
\text { Bile } \\
\text { Sugar } \\
\text { Sediment } \\
\end{array}$} & 1,350 & $\begin{array}{c}1,200 \\
6 \\
1,004 \\
\begin{array}{c}\text { Alkaline } \\
\frac{1}{8} \%\end{array}\end{array}$ & $\begin{array}{c}1,200 \\
12.12 \\
\text { Pale } \\
\\
1,012 \\
33.55 \\
\text { Acid } \\
\frac{1}{8} \%\end{array}$ & $\begin{array}{c}450 \\
3.42 \\
\text { Pale } \\
\\
1,005 \\
5.24 \\
\text { Acid } \\
1 \%\end{array}$ & $\begin{array}{c}1,200 \\
9.12 \\
\text { Pale } \\
\\
1,010 \\
27.96 \\
\text { Acid } \\
\frac{1}{2} \%\end{array}$ & $\begin{array}{c}1,110 \\
6.99 \\
\text { Pale } \\
\\
1,010 \\
2686 \\
\text { Faintly acid } \\
\frac{1}{2} \%\end{array}$ \\
\hline & August 7, 1905 & August 8, 1905 . & August 31, 1905. & September 6, 1905. & November 23, 1905 . & January 15, 1906. \\
\hline \multirow[t]{2}{*}{$\begin{array}{l}\text { Amount } \\
\text { Urea } \\
\text { Color } \\
\text { Chlorides } \\
\text { Specific gravity } \\
\text { Solids } \\
\text { Reaction } \\
\text { Albumen } \\
\text { Bile } \\
\text { Sugar } \\
\text { Sediment }\end{array}$} & \begin{tabular}{|c|}
900 \\
5.67 \\
Pale \\
Diminished \\
1,009 \\
18.87 \\
Slightly alkaline \\
$\frac{1 \%}{1 \%}$
\end{tabular} & $\begin{array}{c}1,200 \\
12.12 \\
\text { Pale } \\
\\
1,012 \\
33.49 \\
\text { Acid } \\
1 \%\end{array}$ & $\begin{array}{c}450 \text { received } \\
4.54 \\
\text { Pale } \\
\\
\\
\text { Acid } \\
\frac{1}{8} \%\end{array}$ & $\begin{array}{c}890 \\
8.98 \\
\text { Pale } \\
\\
1,006 \\
12.44 \\
\text { Acid } \\
\frac{1}{8} \%\end{array}$ & \begin{tabular}{|c|}
2,000 \\
17.60 \\
Pale \\
1,006 \\
27.96 \\
Acid \\
$\frac{1}{8} \%$ \\
Much; chiefly \\
b a c te r i a; \\
many granu- \\
lar epith e lia \\
of medium \\
s i z e f f e w \\
s q u m o u s \\
e p i t h e li a; \\
m a n y f a t \\
globules free \\
and adherent \\
to medium \\
e p i t h e li a. \\
A very few \\
hyaline casts, \\
with fat glob- \\
ules adherent. \\
A fewgranular \\
c a s t s. The \\
hyaline casts \\
of large size. \\
A few blood \\
corpuscles.
\end{tabular} & 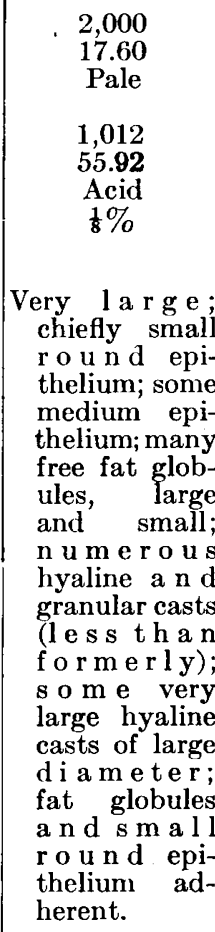 \\
\hline & March 12, 1906 & June 13, 1906. & July $12,1906$. & October $22,1906$. & March 12, 1907 & March 1, 1908. \\
\hline $\begin{array}{l}\text { Amount } \\
\text { Urea } \\
\text { Color } \\
\text { Chlorides } \\
\text { Specific gravity } \\
\text { Solids } \\
\text { Reaction } \\
\text { Albumen } \\
\text { Bile } \\
\text { Sediment }\end{array}$ & $\begin{array}{l}\text { Large; chiefly } \\
\text { s m a } 11 \text { a n d } \\
\text { medium epi- } \\
\text { thelium, fatty } \\
\text { and granular. } \\
\text { Many hyaline, } \\
\text { g r a n u l a r } \\
\text { and t a t t y } \\
\text { casts; some } \\
\text { casts with epi- } \\
\text { thelium ad- } \\
\text { herent. }\end{array}$ & $\begin{array}{c}\text { M o d e r a te } \\
\text { chiefly granu- } \\
\text { lar and fatty } \\
\text { e p i th elium; } \\
\text { few (very few) } \\
\text { granular and } \\
\text { fatty casts. }\end{array}$ & $\begin{array}{c}\text { Pale } \\
1,008 \\
\text { Acid } \\
\begin{array}{c}\text { Very slight } \\
\text { trace }\end{array}\end{array}$ & $\begin{array}{c}\text { Slight; chiefly } \\
\text { h y a l i n e, } \\
\text { granular and } \\
\text { fatty casts; } \\
\text { m e d i u m , } \\
\text { s qu a m o u s } \\
\text { and small } \\
\text { ro und epi- } \\
\text { thelium, first } \\
\text { and last fatty } \\
\text { in many in- } \\
\text { stances; a } \\
\text { little blood. }\end{array}$ & $\begin{array}{c}2,500 \\
15.75 \\
\text { Pale } \\
\\
1,004 \\
\text { Acid } \\
\text { Slight trace }\end{array}$ & 600 \\
\hline
\end{tabular}


amount of fat, and the mucous membrane is pale and smooth. The renal artery is apparently of very small caliber, the diameter of its lumen being about $2 \mathrm{~mm}$. the ureters are small and collapsed, their mucous membrane, as well as that of the bladder, is smooth and pale.

Genitalia. - Appear perfectly normal.

Aorta. - Throughout there are discrete slightly elevated patches of a deeper yellow color than the surrounding yellowish-white smooth intima. This condition is especially marked about the commencement of the intercostal vessels.

Bone marrow. - Of light pinkish-red color for the most part, in which there is a small amount of fat.

Head. - Not opened.

\section{ANATOMICAL DIAGNOSES.}

Chronic glomerulo-nephritis; active bone marrow peritoneal adhesions (local); hypertrophy of hear (slight); arteriosclerosis (slight); malnutrition.

Kidneys. - The glomeruli vary greatly in size; some are enlarged in toto; others show marked dilatation of the capsular space. The tufts throughout are more or less lobulated; show considerable increase in the number of nuclei, indicating a total cellular increase, and there is marked increase of fibrous connective tissue, some of which is hyaline. This does not give any amyloid reaction. The distended capsular spaces contain varying amounts of circular reticulum. The capsules show very extensive increase of connective tissue, immediately surrounding them. The lining pavement epithelium is unchanged. The convoluted tubules are conspicuously absent. Those that remain are in many instances dilated and contain very low cuboidal epithelium which show very little fat; but those tubules of normal size contain epithelium of normal size, the nuclei and protoplasm of which stain very faintly. These cells contain a great deal of fat in clumps and fine granules. The hyaline substance in the tufts, much of the granular deposit in the capsules and the hyaline casts take a similar pale yellowish-red tint differing somewhat from the deep orange-red of the large fat droplets. The loops of Henle and the collecting tubules show fair preservation. The interstitial tissue is everywhere markedly increased, but not more so about the vessels than elsewhere. The tubules are compressed by it and there are numerous groups of nuclei arranged about a tiny lumen or in a circle without a lumen, which apparently represent atrophied convoluted tubules. Lymphoid cells are found scattered pretty evenly throughout the interstitial tissue of the cortex, but more particularly just under the capsule. They are uniformly of the small round cell type. The capsule is very markedly thickened, consisting of very dense hyaline connective tissue with few nuclei. There is a large amount of fat scattered throughout this tissue, the droplets always lying at the ends of the elongated nuclei. There is a good deal of fat also scattered throughout the interstitial tissue. The arteries show no intimal thickening.

Lymphoid tissue. - Retroperitoneal lymph nodes show perfectly quiescent lymph follicles (no germinal centers). The sinusoids are distended and mostly filled with granular detritus, a few lymphocytes, red corpuscles, and, most of all, with oval and short spindle cells and with acidophilic protoplasm, indefinite cell boundaries and a large oval vesicular nucleus. Such large cells often show protoplasmic processes which appear to unite with the reticulum, and their nuclei are precisely like the reticular cell nuclei. None of these cells are phagocytic.
PLACENTA PR EVIA.

An Analysis of 155 Cases delivered at the Boston Lying-in Hospital during the Past Thirty-Five YeARS.

$$
\text { BY NATHaNiEL R. Mason, M.D., }
$$

Assistant in Obstetrics and Gynecology, Harvard University; Physician Out-Patients, Boston Lying-in Hospital: Third Assistant Visiting Surgeon for Diseases of Women, Boston City Hospital. AND

JOHN T. WILLIAMS, M.D., BOSTON.

Now that Cesarean section and other operations have so far solved the problem of the management of labor in contracted pelves as to reduce it to a scientific application of these methods of delivery to the proper cases, more attention is becoming directed to the two other great obstetrical problems, eclampsia and placenta prævia. In the hope of adding something to the knowledge of the latter condition, the writers have gone over the records of the Boston Lying-in Hospital for the past thirty-five years, and will set forth briefly in this paper the results of their study. This included 155 cases of placenta prævia, of which there were 55 complete, 51 partial and 49 marginal.

The frequency of placenta prævia has been variously estimated at from once in 250 cases in hospital to once in 1,000 in private practice. It has heretofore been considered impossible to obtain an accurate idea of its actual frequency by hospital statistics, since such institutions of necessity receive an undue proportion of abnormal cases. An inquiry into the number of cases among the out-patients of the hospital, however, should give an accurate estimate of its frequency among all pregnancies, because this class of patients apply first to the hospital for practically any complaint during pregnancy, and are always attended by the externes of the hospital at confinement. Among 32,453 outpatients, during a period of twenty-seven years, from 1881 to 1908 , there were encountered 11 cases of complete, 19 of partial and 15 of marginal placenta prævia, making a total of 45 , about 1 to every 700 pregnancies.

Of the etiology of placenta prævia little is known. That it is more common in multiparæ seems to be established, and that this frequency increases as the insertion of the placenta is marginal, partial or central, is shown by our series in which there were respectively 80,86 and $90 \%$ of multiparæ. Furthermore, the liability to the complete variety seems to increase with the number of pregnancies, as is shown in the following table:

$\begin{array}{lcc}\text { Average age. } & \begin{array}{c}\text { Average number } \\ \text { of pregnancy. }\end{array} \\ \text { Complete, } & 31.8 & 5.4 \\ \text { Partial, } & 32.2 & 5.1 \\ \text { Marginal, } & 27.4 & 3.7\end{array}$

At the same time, however, placenta prævia does occur with sufficient frequency in primiparæ to be the first thing which should be thought of whenever there is uterine hemorrhage during the latter half of pregnancy.

Upon the importance of previous inflammatory changes in the endometrium in its pro- 